Article

\title{
Business Model Innovation through a Rectangular Compass: From the Perspective of Open Innovation with Mechanism Design
}

\author{
JinHyo Joseph Yun * (1) and Xiaofei Zhao \\ Department of Open Innovation and Business Model, Open Innovation Academy of SOI, Daegu Gyeongbuk \\ Institute of Science and Technology, Daegu 42988, Korea; qiaoke@dgist.ac.kr \\ * Correspondence: jhyun@dgist.ac.kr
}

Received: 25 August 2020; Accepted: 26 October 2020; Published: 1 November 2020

check for updates

\begin{abstract}
We aim to develop an innovative way to alter existing business models to conquer the growth limits of exponential paradox by applying the open innovation concept to the design of creative business models. Our research question is as follows: How can we innovate existing business models more easily based on our own thinking experiment at the role-place of ourselves in the open innovation knowledge funnel? We built a rectangular compass concept model and carried out social experiments with it for 3.6 years from November 2014 to May 2019 by developing 17 business model patents to validate the model. The rectangular compass concept model has four aspects: over-shooting of modern business models, expanding the bottom of modern business models, cultivating the forward neighborhood of modern business models, and cultivating the backward neighborhood of modern business model. According to our study, open innovation, which is based on a new combination between technologies (protected technology, protectable technology, and social technology) and market (now market, potential market, and social market), is the engine of sustainable business model innovation dynamics.
\end{abstract}

Keywords: open innovation; business model; rectangle compass; new combination; bounded rationality; mechanism design

\section{Introduction}

Even though the evolution of technological advances has been occurring at an exponential rate beginning with IT revolution and continuing through the 4th industrial revolution, the growth of economic productivity is not increasing in kind and is even decreasing in many countries [1]. The slowdown of productivity, exhausted opportunities, and the power of human ingenuity are turning the world upside down in terms of entrepreneurial decline and the exponential paradox [2,3]. In the face of this serious situation, diverse ideas to address the issue have been proposed, such as opening up the innovation process, basic income with high open innovation dynamics, or micro- and macro-dynamics of open innovation with quadruple helix, as potential approaches to conquer the growth limits of modern capitalism [1,4-7]. Furthermore, a creative business model based on a new combination of technology and market is receiving attention as a concrete way of conquering the growth limits in firm level [8]. With the development of a concept design of a nine-factor business model and the appearance of open business model theory, the path from open innovation to a creative new business model is emerging as the new research agenda of the open innovation business model [9-11]. We hope to develop a new approach by applying the open innovation concept to transform the existing business model into a creative business model. Our research question is as follows:

How can we innovate existing business models more easily based on our own thinking experiment at the role-place of ourselves in the open innovation knowledge funnel? 
We intend to answer this question by building a concept model and by conducting social experiments involving applying this model to social reality. If we innovate our business model continuously from the open innovation dynamics, we could conquer the growth limits of capitalism in the end. So, the research question of this study can be justified as a new approach from open innovation to business model.

\section{Literature Review and Research Framework}

\subsection{Literature Review}

Business model research originally developed from e-commerce, which grew from the development of information technology and the internet in the 1990s (Zott, Amit, and Massa, 2011). As the demand for customers to be able to interact with companies anytime and anywhere increases, the importance of business models is becoming more important [12]. Though until around 2000-2001, a business model was defined as a kind of description or statement, it has since been accepted as a kind of concept model or architecture $[9,11,13]$. Recent business model studies, such as business model prism for arts and cultural organizations, open principles in new business models, dynamics in business model frameworks, and a new and emerging business model of artificial intelligence including relevant platforms, are almost all focused on concept model or architecture [14-16]. The common definition of a business model from the concept model or architecture perspective is "the concept model or architecture which provides value proposition, and revenue creation" [17].

Presently, business model research has shifted from analyzing existing business models to developing new business models with concrete components. After "business model canvas" was defined using nine factors, such as value propositions, customer relationships, customer segments, key partners, key activities, key resources, cost structure, and revenue streams, most business model concept models have followed the canvas, even though the approaches to developing a business model are diverse [9]. There are several examples of business models, such as: a business model compass with the five Ws and one $\mathrm{H}$, with "who" as customer segmentation, "what" as value proposition, "why" as cost and revenue, "when" and "where" as the customer relations and channels, and "how" as the technological system with key resource, key partners, and key activities; or the market value framework with the target market, value proposition, and market offerings; or the four elements of successful business models, that is, customer value proposition, key resources, key processes, and profit formula et al. $[8,10,11,18]$.

Furthermore, the business model as a cognitive map across domains for open innovation serves as an intermediate construct that links the technical and economic domains descended from the concept of new combinations, which means combining diverse materials and forces differently and covers five cases (the introduction of a new good, the introduction of a new method of production, the opening of a new market, the conquest of a new source of supply of raw materials of half-manufactured goods, and the carrying out of the new organization of any industry, such as the creation of a monopoly position) [19]. Open innovation as an open connection between technology and market across the firm boundary includes the business model. This means new combinations or recombination between technology and market because open innovation requires each company to open up its business models to allow more external ideas and technology flow in from the outside and to permit more internal knowledge flow to the outside $[10,11,20]$.

The basic idea of combining the relationship between open innovation and business model comes from the open innovation business model concepts of Henry Chesbrough [10,21]. Business models are not just about technology anymore-open innovation business models motivate the growth of new revenue streams such as sale/divestiture, spin-offs, licensing, and decrease of costs such as cost and time savings from leveraging external development [10,22]. Open innovation in business models, which is a new perspective to connect technology and market, and business models for open innovation, 
which match heterogeneous open innovation strategies with business model dimensions, show that open innovation is appearing as a way to build new business models [23,24].

Considering such a relationship with open innovation, several ideas for enlarging business models, including business model transformation and the creation of new business models, were developed. The value proposition canvas creates new business models by connecting value proposition and customer segmentation, such as gain creators or pain relievers [25]. The customer development model proposes a way to launch lean start-ups, which means the enlargement or the new building of a business model through the interaction of four steps: customer discovery, customer validation, customer creation, and company building [26]. The blue ocean shift strategy illustrates a new approach to value creation through rocket shooting, expanding boundaries, and so on [27]. Through disruptive technologies or reinventing a business model in the value chain, business models can be enlarged, or new business models can be created $[8,28]$. If any linear supply chain structure is changed as a network of suppliers and customers, that change can act as a way of enlarging existing business models [29].

\subsection{Research Framework}

We innovated the modern business model using a rectangular compass that has four aspects: over-shooting of the modern business model, expanding the bottom of the modern business model, cultivating the forward neighborhood of the modern business model, and cultivating the backward neighborhood of the modern business model. We designed the concept model as shown in Figure 1. Furthermore, if the rectangular compass is applied to the open innovation knowledge funnel, the four rectangular aspects can be matched to four agents who develop business models at the four locations of the open innovation knowledge funnel, as in Figure 2 [24].

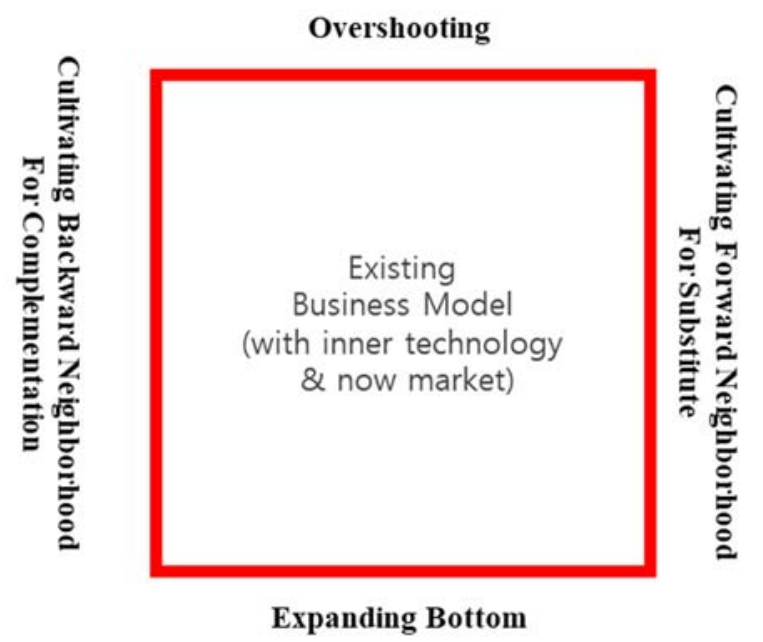

Figure 1. Research Framework I: rectangular compass concept building for business model innovation.

In the knowledge funnel, users, that is, the existing firms, can innovate the modern business model mainly by cultivating the forward neighborhood and the change value, as in $\alpha$ in Figure 2 . An engineer in the knowledge funnel can innovate the modern business model by cultivating the backward neighborhood, that is, research or technology sources, as in $\beta$ in Figure 2.

Customers and social entrepreneurs are not located inside of the funnel but rather in front of it. Therefore, a customer can innovate the modern business model mainly by overshooting either upward or downward from the modern business model, as in $\gamma$ in Figure 2. Finally, social entrepreneurs can innovate the modern business model mainly by expanding it from the bottom upward or downward, as in $\delta$ in Figure 2. 


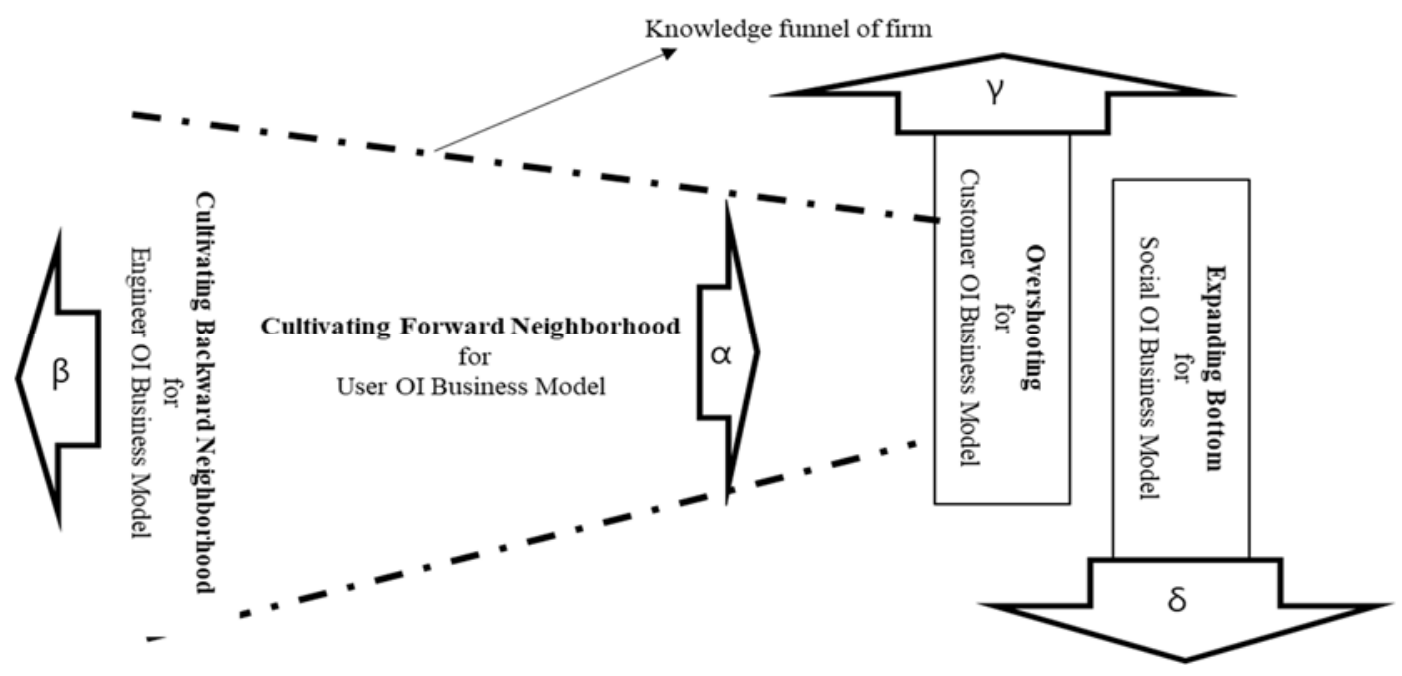

Figure 2. Research Framework II: rectangular compass in the knowledge funnel.

\subsection{Research Scope and Method}

First, this study developed and examined a "rectangular compass" concept model for business model innovation from the perspective of open innovation. The rectangular compass concept model was developed through a literature review of the Schumpeterian new combination, through bounded rationality by Herbert Simon, mechanism design by William Vickrey, and finally the open innovation business model of Henry Chesbrough [10,19,30-32]. Business model innovation from open innovation is based on Chesbrough [10]. Open innovation dynamics, which means dynamic aspects of open innovation and motivates sustainable business model innovation, is from the bounded rationality of the human being, which was proposed by Herbert Simon, and new combination, which was proposed by Joseph Schumpeter [19,30,32]. Business model design by business model compass, and business model innovation by rectangle compass, are based on the mechanism design, which was proposed by William Vickrey, who won the 1996 Nobel Memorial Prize for Economics, from open innovation to business model [31].

Second, social experiments applying the rectangular compass to develop an innovative business model through open innovation, and the business model research team of Daegu Gyeongbuk Institute of Science \& Technology (DGIST) between November 2014 and May 2018, have been conducted and then compared with earlier social experiments conducted when this research team developed a business model design compass between January 2011 and August 2014 (see Table 1). 
Table 1. Social experiment with a rectangular compass, and business model of an open innovation funnel.

\begin{tabular}{|c|c|c|c|}
\hline \multicolumn{2}{|c|}{$\begin{array}{c}\text { First Social Experiment to Develop a Business Model } \\
\text { Design Compass } \\
\text { (January 2011-August 2014) }\end{array}$} & \multicolumn{2}{|c|}{$\begin{array}{c}\text { Second Social Experiment to Develop a Rectangular Compass for } \\
\text { Innovating a Business Model } \\
\text { (November 2014-May 2018) }\end{array}$} \\
\hline BM of OI funnel & Patent Title (Application Number) & $\begin{array}{l}\text { Rectangular } \\
\text { Compass }\end{array}$ & Patent Title (Application Number) \\
\hline \multirow{5}{*}{$\begin{array}{l}\text { Customer OI } \\
\text { based BM }\end{array}$} & \multirow{3}{*}{$\begin{array}{l}\text { Smart real-time concert system and } \\
\text { method thereof }(10-1282743)\end{array}$} & \multirow{5}{*}{$\begin{array}{l}\text { Overshooting } \\
\text { Rectangle }\end{array}$} & $\begin{array}{l}\text { Smart library management apparatus and } \\
\text { method thereof }(10-2015-0152005)\end{array}$ \\
\hline & & & $\begin{array}{l}\text { Navigation device and method of providing } \\
\text { emotional drive route using the same }\end{array}$ \\
\hline & & & \\
\hline & \multirow{2}{*}{$\begin{array}{l}\text { Cleaning robot control method and } \\
\text { apparatus based on autonomous } \\
\text { learning (10-2014-0053594) }\end{array}$} & & $\begin{array}{l}\text { System of sharing photo-based location and } \\
\text { method thereof }(10-2016-0123128)\end{array}$ \\
\hline & & & $\begin{array}{c}\text { Smart vehicle cleaning system for improving } \\
\text { environment vehicle space and method } \\
\text { thereof }(1020180100471)\end{array}$ \\
\hline \multirow{4}{*}{$\begin{array}{l}\text { Social Entrepreneur } \\
\text { OI based BM }\end{array}$} & \multirow{2}{*}{$\begin{array}{l}\text { Smart Weekend farm system } \\
\quad(10-2011-0120524)\end{array}$} & \multirow{4}{*}{$\begin{array}{l}\text { Expanding Bottom } \\
\text { Rectangle }\end{array}$} & $\begin{array}{l}\text { Smart guard apparatus and method thereof } \\
\qquad(10-2015-0152007)\end{array}$ \\
\hline & & & $\begin{array}{l}\text { System for improving smart social values } \\
\text { promoting using networks (10-2016-0123353) }\end{array}$ \\
\hline & \multirow{2}{*}{$\begin{array}{l}\text { Smart social library service } \\
\quad(10-2012-0010317)\end{array}$} & & $\begin{array}{l}\text { Sharing-based smart parking management } \\
(10-2016-0123124)\end{array}$ \\
\hline & & & $\begin{array}{l}\text { System for behavior control of companion } \\
\text { animal using user terminal (10-2018-0055485) }\end{array}$ \\
\hline \multirow{4}{*}{ User OI based BM } & $\begin{array}{l}\text { Real estate development information } \\
\text { intermediate method and system } \\
\text { 10-2012-0012973 }\end{array}$ & \multirow{4}{*}{$\begin{array}{l}\text { Cultivating Forward } \\
\text { Neighborhood } \\
\text { Rectangle }\end{array}$} & $\begin{array}{l}\text { Smart meditation apparatus for improving } \\
\text { concentration and operation method thereof } \\
\text { (10-2014-0151358) }\end{array}$ \\
\hline & $\begin{array}{l}\text { Time- and location-based survey } \\
\text { marketing service providing server } \\
\text { and method thereof (10-2012-0010027) }\end{array}$ & & $\begin{array}{l}\text { Indoor harmful gas emissions system } \\
\qquad(10-2014-0153686)\end{array}$ \\
\hline & $\begin{array}{l}\text { Art module apparatus for driving and } \\
\text { controlling method thereof } \\
(10-2014-0054960)\end{array}$ & & $\begin{array}{l}\text { Interactive smart display advertisement } \\
\text { platform system and advertisement service } \\
\text { method using the same (10-20180040508) }\end{array}$ \\
\hline & $\begin{array}{l}\text { System for preventing drowsy driving } \\
\text { by one touch and method thereof } \\
(10-2014-0053593)\end{array}$ & & $\begin{array}{c}\text { Store signboard-type smart display } \\
\text { advertisement platform system and } \\
\text { advertisement service method using the same } \\
(10-2019-0085833)\end{array}$ \\
\hline \multirow{5}{*}{$\begin{array}{c}\text { Engineer OI } \\
\text { based BM }\end{array}$} & \multirow{2}{*}{$\begin{array}{l}\text { Feedback public relations server and } \\
\text { method of manufacturing homepage } \\
\text { using thereof 10-2013-0069705 }\end{array}$} & \multirow{5}{*}{$\begin{array}{l}\text { Cultivating } \\
\text { Backward } \\
\text { Neighborhood } \\
\text { Rectangle }\end{array}$} & $\begin{array}{l}\text { System for advertisement using smart bench } \\
\text { and method thereof }(10-2015-0160388)\end{array}$ \\
\hline & & & $\begin{array}{l}\text { Smart locking system using user terminal and } \\
\text { unlocking method thereof (10-2015-0172548) }\end{array}$ \\
\hline & $\begin{array}{l}\text { Bed system for the detection of sleep } \\
\text { and sleep state detection method } \\
\text { 10-2013-0144024 }\end{array}$ & & $\begin{array}{l}\text { System for electronic car charge reservation } \\
\text { and management method thereof } \\
(10-2018-0039146)\end{array}$ \\
\hline & $\begin{array}{l}\text { Open business platform service } \\
\text { method and apparatus thereof } \\
10-2013-0137001\end{array}$ & & $\begin{array}{l}\text { Mobile smart advertisement platform system } \\
\text { and advertisement service method using the } \\
\text { same (10-2018-0042169) }\end{array}$ \\
\hline & $\begin{array}{c}\text { Network system for inter-vehicle and } \\
\text { method thereof } \\
10-2014-0106828\end{array}$ & & $\begin{array}{c}\text { Smart terminal and method for measurement } \\
\text { of object length using the same } \\
(10-20150083337)\end{array}$ \\
\hline
\end{tabular}

\section{Overshooting Rectangular Compass Building and Social Experiment}

\subsection{Concept Model Building of Overshooting Rectangular Compass}

A smart yacht started its life in April 2012 with the name of Venus, designed by Steve Jobs, the legendary Apple cofounder who died one year prior. As the fascinating creator of the yacht, Steve Jobs did not know anything about yachts but designed it himself in collaboration with a top global yacht designer $[33,34]$. James Dyson developed the cyclone technology-based vacuum cleaner because of his dissatisfaction with and desire to improve existing products-what has been termed "constructive discontent" [35]. Steve Jobs designed the NeXT's grand staircase, which seemed to float in the air, for his own usage, at great financial cost and through numerous repeated processes; some years later, Jobs would make such staircases a feature in Apple's signature stores [36]. 
An overshooting rectangular concept model can be built from the refined customer's perspective, as in Figure 3. First, the target customer of this business, that is, the customer segmentation, is the non-customer who refuses to become a customer right now because he or she is a highly refined potential customer [27]. The customer as a migrator will pursue value improvement in this business model innovation [27].

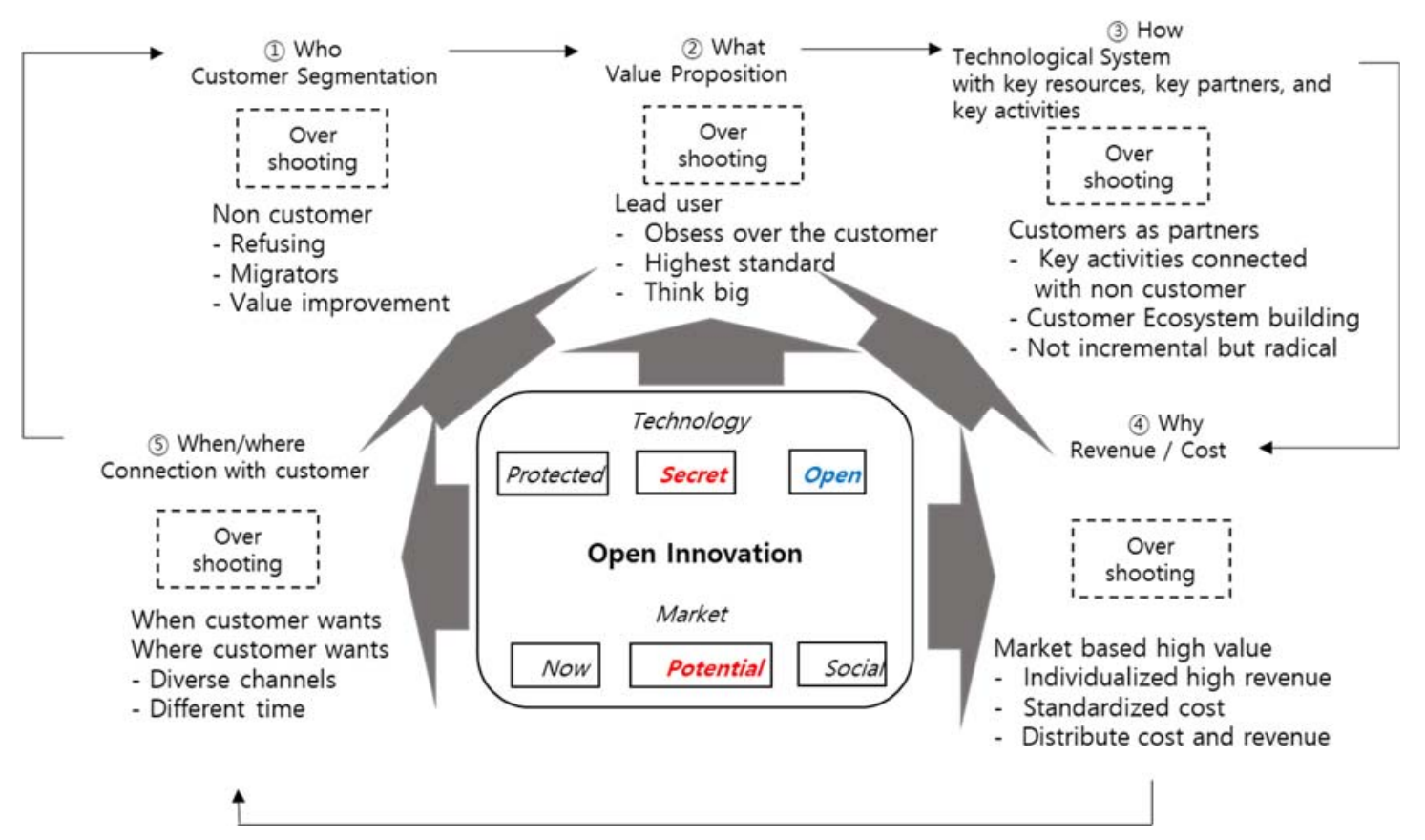

Figure 3. Overshooting rectangular concept model for customer-centered business model innovation.

Second, value proposition in customer-centered business model innovation requires attention to customers' requirements based on the highest standard and originating from thinking big [37]. Reviewing need and solution data from "lead users" can improve productivity in terms of new product development in fields characterized by rapid change by elucidating innovative and new value propositions [38].

Third, technological systems with key resources, key partners, and key activities in customer-centered business model innovation are required to treat customers as partners by organizing key activities to facilitate connection with non-customers. We should keep in mind that entrepreneurs are everywhere [39], but higher value that meets the requirements of overshooting customers should come through in a minimum viable product (MVP). By making the technical system a customer co-creation ecosystem with a platform structure, a customer-centered business model makes itself difficult to copy [40]. Changing the technological system in the process of customer-centered business model innovation is sometimes not incremental but instead can be quite radical [41].

Fourth, revenue and cost are why customer-centered business model innovation pursues market-based high value, which has individualized high revenue and standardized cost. Diverse individualized services or products, such as individual training, individual consulting or teaching, individual bodyguards, individual restaurants, individual clothes, individual riding, individual shoes, individual cars, individual golf sets, etc. can produce high values by meeting the requirements of customers. Furthermore, standardization of components or service process can decrease total costs of customer-centered business models. In addition, by transforming existing business models through services, cost and revenue can be distributed over the long term as a kind of subscription economy, which will decrease the financial risk of startups and promote cumulative cash flow for startups [42,43].

Fifth, there must be connection with customers in "when" and "where" customer-centered business model innovation is pursued-that is, when and where the customer wants. In the process 
of gaining customers, from acquiring through activating to retaining, the number of customers will decrease as the acquisition customers grows from up-selling through next selling to cross-selling [44]. Sophisticated designs of customer channels as well as customer relationships should be focused on to target non-customers [9].

As shown in Figure 3, open innovation in a potential market is critical, and secret or open technology will motivate the overshooting rectangular business model innovation dynamics from "who" (customer segmentation) to "when" and "where" (customer relation and channel).

\subsection{Social Experiment and Validation of Overshooting Rectangle-Based Business Model Innovation}

First, according to our social experiments, the overshooting rectangle focused on refusing customers who want to improve values as migrators, as shown in Table 1. The smart library management system has target customers who reject normal bookstands or smart bookshelves and want to connect a physical bookstand and smart bookshelf as migrators. The emotional navigation device focused on customers who dislike short-cut navigation, and pursue emotional roads with suitable music, which means increasing value and migrators. The location-based photo sharing system has customers who deny only photos with no accompanying map-based information about location and want to enjoy photos with the concrete information of location and time as migrators to pursue increasing the value of the photos. The smart vehicle cleaning system appeals to customers who hate dust in the air and want to utilize the redundant energy of their car engine to improve the value of the car as migrators. In our social experiment, the overshooting rectangle gave us additional innovative business model ideas beyond just customer-based customer segmentation in the business model design compass [11].

Second, the overshooting rectangle pursued value proposition with the highest standard from thinking big by lead users or obsessed customers according to our social experiments in Table 1 . Four examples - the smart library management system, emotional navigation, location-based photo sharing system, and smart vehicle cleaning system-all meet the highest standard of thinking big by customers. According to this social experiment, not just customer-focused value proposition, but customer-based overshooting with highest standard motivated innovation of business models.

Third, according to our social experiment, the overshooting rectangle focused on technological systems that have customers as partners, key activities connected with non-customers in addition to customer ecosystem building, and radical rather than incremental systems. Almost all cases, such as the smart library management system, emotional navigation, and location-based photo sharing system, pursued customer ecosystem building, meaning having customers as partners; the only exception was the smart vehicle cleaning system.

Fourth, according to our social experiment, the overshooting rectangle focused on market-based high value with individualized high revenue and standardized cost in addition to distributed cost and revenue. Nearly all cases, including the smart library management system, emotional navigation, location-based photo sharing system, and smart vehicle cleaning, focused on individualized high revenue according to customers and standardized cost for all customers. The overshooting rectangle gave chances of more innovative cost-revenue business model design.

Fifth, the overshooting rectangle pursued customer relations and channels that meet the requirements of customers. The smart library management, emotional navigation, location-based photo sharing system, and smart vehicle cleaning all pursued customer relationships and channels that were based on customer requirements. The overshooting rectangle provided opportunities to highly improve the customer relationships and channels.

All four social experiment cases were based on open innovation between potential markets and secret or open technology, as shown in Figure 3. Through connections and new combinations between not current but potential markets and secret or open technology, the overshooting rectangle motivated business model innovation that was based on customers' open innovation, according to our social experiment. 


\section{Expanding Bottom Rectangular Compass Building and Social Experiment}

\subsection{Concept Model Building of Expanding Bottom Rectangular Compass}

In Ghana, the social company "Burro" started business by renting rechargeable batteries, which was a very low-level business, as renting rechargeable batteries created very low value with almost no revenue [45]. Now, however, the social company has expanded its social value to include market value by renting and selling diverse energy machines in Africa [4]. The founder of Honey Bee, which is a kind of social innovation network with global boundaries, noted that mobilizing social and ethical capital with intellectual capital and natural capital can motivate creative market innovations and provided substantial evidence from India, such as an inclined drinking-water pipe to enable children of different heights to drink water easily, a motorcycle that will not start unless one wears a helmet, a modified walker, etc. $[46,47]$. Social open innovation, that is, open innovation in organizations that seek to achieve positive social changes as their primary mission by applying either inbound or outbound open innovation strategies, along with innovations in the associated business models of the organization, can ultimately motivate both social value and market value in the dynamic of social enterprises $[48,49]$. In fact, creating shared value, that is, social value, is a way to reinvent capitalism and unleash a wave of innovation and growth [50].

The expanding bottom rectangular concept model can be built from the perspective of social entrepreneurs, as in Figure 4. First, the customer segmentation of this business model involves denying customers because the product is too expensive, too big, or too luxurious. That is, less attractive but in-need customers are targeted as an unrecognized customer segment. The requirements of this customer segment can be met by being more responsive to public needs as pain relievers rather than to business needs $[25,51]$.

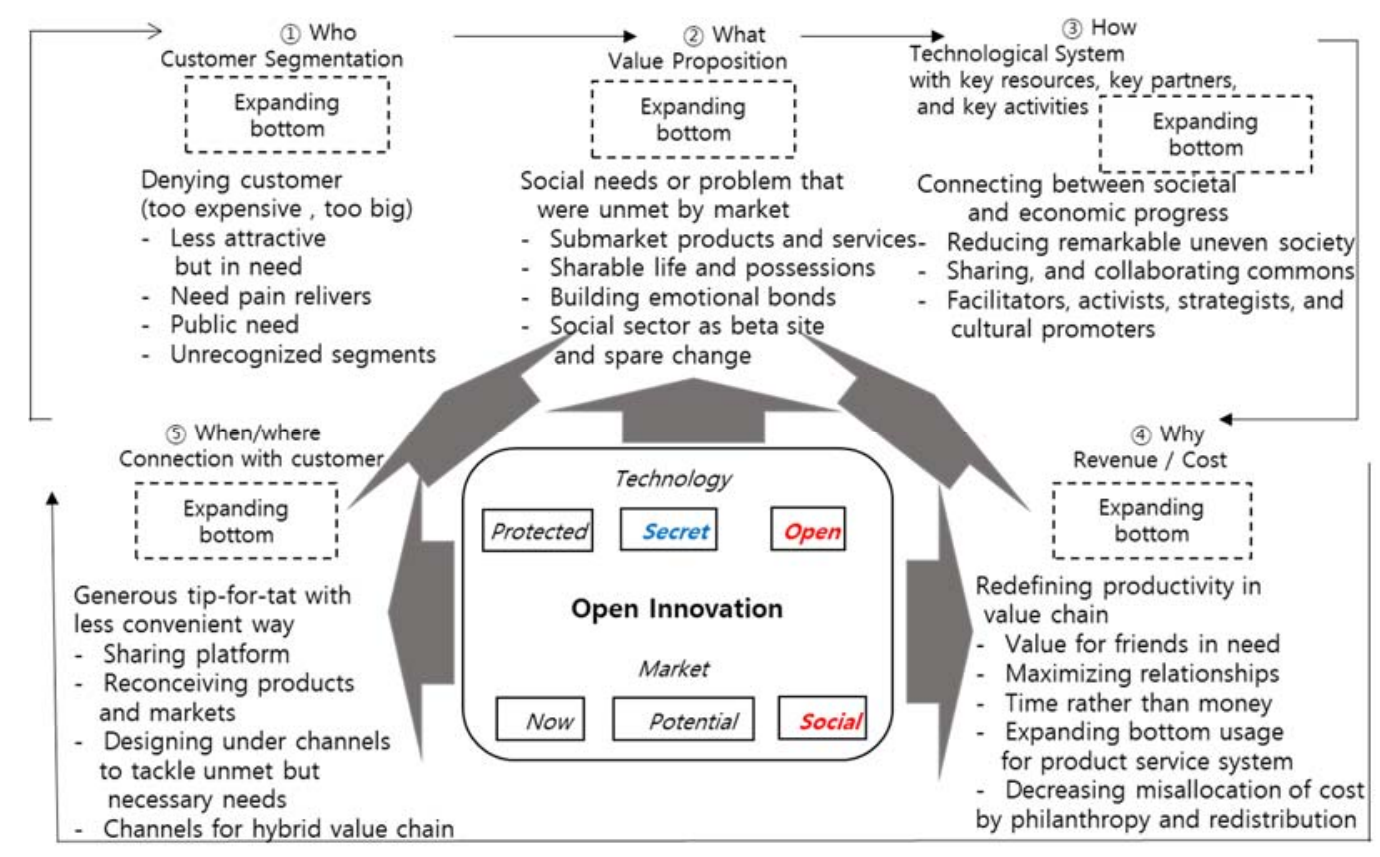

Figure 4. Expanding the bottom rectangular concept model for social entrepreneur-centered business model innovation.

Second, value proposition in social entrepreneur-centered business model innovation requires social needs or problems that are unmet by the market $[52,53]$. Submarket products and services including a sharable life and possessions can be obtained by expanding the bottom [50]. A social sector that builds emotional bonds is a target of value proposition for the expanding bottom and is the key to integrating social benefits with company strategy [54]. 
Third, in a social entrepreneur-centered business model innovation, a technological system for connecting social and economic progress is needed to reduce dramatic imbalance in a society, as capital income was significantly greater than labor income in the late 20th century and in the 21st century $[50,55,56]$. Technological systems as facilitators, activists, strategists, and cultural promoters of sharing and collaborating commons constitute a target of the expanding bottom $[57,58]$.

Fourth, cost and revenue in social entrepreneur-centered business model innovation requires redefining productivity in the value chain by maximizing not profits but friends and relationships, even though these are less attractive from the cost and revenue perspectives, by accepting the collaborative commons as social capital with a creative mechanism design $[51,59,60]$. A product service system (PSS) with collaborative consumption will expand bottom users with collaborative lifestyles [61]. Through philanthropy and redistribution, the expanding bottom rectangle can decrease misallocation of costs [31,62].

Fifth, generous, if less convenient, tit-for-tat is recommended in customer channels and relations in terms of the "when" and "where" of social entrepreneur-centered business model innovation. Generous tit-for-tat is a type of customer relation strategy that means "never forget a good turn, but occasionally forgive a bad one as $1 / 3$ ratio," because generous tit-for-tat can easily nullify tit-for-tat and defend itself against being exploited by defectors [63]. Through channels such as hybrid value chains or sharing platforms, designing under-channels to tackle unmet but necessary needs is possible (Chesbrough and Di Minin, 2014). By reconceiving products and markets from the perspective of denying customers, it is possible to arrive at new customer channels and relations under the bottom of modern channels and relations [48].

As shown in Figure 4, mainly open innovation between social markets and secret or open technology will motivate the expanding bottom rectangular business model innovation dynamics in regard to the "who" of customer segmentation and the "when" and "where" of customer relations and channel. Though social entrepreneurs are presently focusing on social markets, they will move from potential markets to current markets in the end.

\subsection{Social Experiment and Validation of the Expanding Bottom Rectangular Compass}

First, the expanding bottom rectangle focused on customers denied because products are too expensive or big according to our social experiments, as shown in Table 1. The smart guard system, for example, targets customers who are denied normal guard systems because they are too expensive. This business model tries to relieve the risk to women and children at night, that is, unrecognized segments who need guards but cannot buy them in the traditional market. Individual smart guards are possible through connecting the societal function of smart phones, and additional economic value is thus generated by this smart guard system.

Second, the smart social value promotion system targets customers who dislike large social network systems because of harsh replies to comments facilitated by anonymity. Non-anonymous social networking systems with no harsh replies constitute an unrecognized segment in the modern economy. Through the expanding bottom, this business model wants to relieve the pain of harsh responses in social network systems. Via social platform building, creating social value promotion and its sharing in society and market could be possible in this expanding bottom rectangular business model.

Third, the sharing-based smart parking management system focused on customers denied because they did not pursue renting their own parking space during times of non-use. By renting non-use time in private parking lots, this system is connecting the social value of empty parking lots and the market value of individuals who own empty parking spots. Redefining the value of private parking lots by offering them for public use is possible by building a sharing platform among private parking lot owners and other parking lot users.

Fourth, the companion animal smart control system focuses on customers denied because they did not pay attention to the safety of other citizens regarding their own pet dogs due to high cost and previously minimal legal regulations. The social need to protect citizens from pet dogs by connecting 
the social value of citizen protection and the market value of smart control for pet dogs expanded the bottom of the companion animal smart control system. Reconceiving the companion animal smart control system made it possible to meet dogs' owners and general citizens through smart customer channels and relationships.

All four social experiment cases were based on open innovation between social markets, such as individual smart guards, smart social value promotion, social sharing of unused private parking lots, and companion animal smart control, and potential or open technology such as the smart guard system, smart social value promotion system, social sharing system for parking lots, and companion animal smart control system.

\section{Cultivating Forward Neighborhood Rectangular Compass Building and Social Experiment}

\subsection{Concept Model Building of Cultivating Forward Neighborhood Rectangular Compass}

Dyson took its original patent on hurricane technology for a "without dust envelope" vacuum cleaner and applied it to an electric fan similar to a jet engine with no wings by applying their patented technology to a new market [64]. Megagen Implant CEO Park, who was a dentist and the president of Mire Network, which had 19 dentist hospitals in Korea among its membership, developed and patented implant technology for use with his own patients who were old and did not have enough jaw bones, which were required to implant artificial teeth, and shifted to a new market of producing implants rather than treating dental patients [65]. Daesek, which produced solar panels, developed an "endless wire saw" that could be used in place of a traditional cutting machine for cutting ingot, which was used for solar energy panels, and expanded its main market to ingot-cutting tools [63].

A cultivating forward neighborhood rectangular concept model can be built from the perspective of the user as an existing small and medium-sized enterprise (SME), as in Figure $5[24,66]$. First, the customer segmentation of this business model is the non-cultivated user because of any change in value, that is, value chain open innovation [67]. By newly defining a consumer group not as non-users but as new users or potential users, this can be considered customer segmentation [68]. In addition, through user community, co-creation with individuals, or from gains in customer insights, customer segmentation is possible for a cultivating forward neighborhood rectangle [25,69].

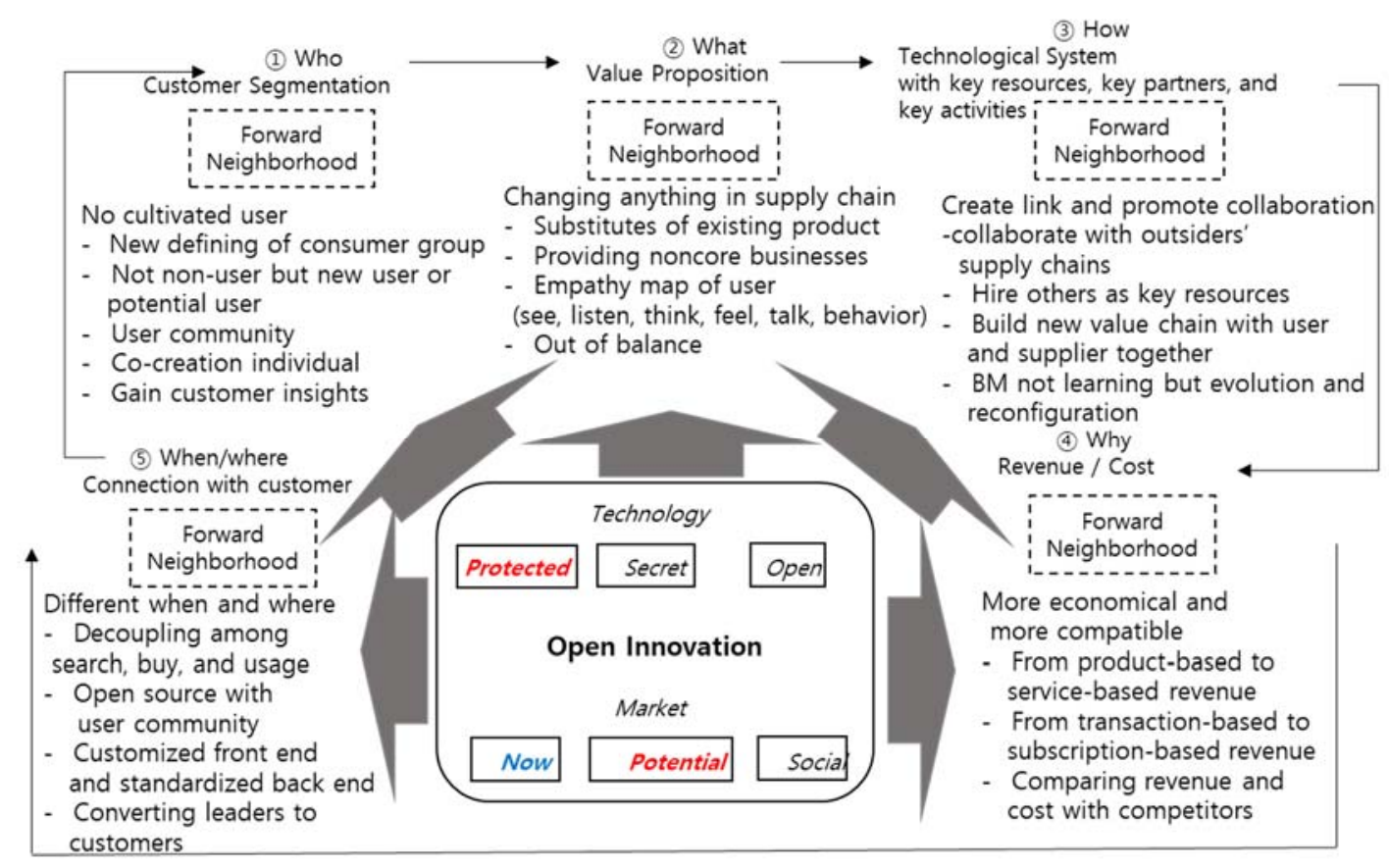

Figure 5. A cultivating forward neighborhood rectangular concept model for user-centered business model innovation. 
Second, value proposition, the "what" of user or existing SME-centered business model innovation, requires changes in the supply chain for substituting existing products or services [28]. Diverse aspects of users such as seeing, listening, thinking, feeling, talking, behavior, etc. through empathy maps can be translated as value proposition [9]. Value proposition of users for composing the rectangle pursues the out of balance or over-refined of an existing business model to create new value [70].

Third, the technological system, the how of user-centered business model innovation, should create links and promote collaboration with others in the value chain to provide orphan products from loonshot projects that focus not on culture or innovation but on creative structure and architecture [71,72]. By building new value chains with user and supplier together in addition to hiring others as key resources, technological system innovation from the perspective of the user is possible not for business model learning but for business model evolution or reconfiguration [73-75].

Fourth, cost and revenue, the "why" of user-centered business model innovation, involve the pursuit of more economical and more compatible cost and revenue [76]. By moving from product-based to service-based revenue, more economical and compatible cost and revenue will be possible [42]. In addition, by moving from transaction-based cost and revenue to subscription-based cost and revenue, additional refining of cost and revenue in this user rectangle is possible [77].

Fifth, customer channel and its relation to the "when" and "where" compass of user-centered business model innovation pursues different "when" and "where" to find new customers by decoupling among search, buy, and usage [78]. Being open source with a user community is a good solution for this channel or related searches [79-81]. In addition, customizing from the end and having a standardized back end can convert leaders to customers [42,81].

Existing SMEs with forward neighborhood cultivating can achieve business model innovation by motivating open innovation between their current protected technology and the existing markets of others located in their value chains or potential market, which can be illustrated in a rectangular compass, as in Figure 5.

\subsection{Social Experiment and Validation of Cultivating Forward Neighborhood Rectangle Compass}

First, the cultivating forward neighborhood rectangle focused on non-cultivated users as shown in Figure 5, according to the social experiments in Table 1. The smart meditation system has target users whom the firm had not previously cultivated. The indoor harmful gas emission system also focuses on users who were not cultivated by the firm that developed this new business model. The interactive smart display advertisement platform system and store signboard-type advertisement platform were developed based on the original ideas of an existing advertisement firm's non-cultivated users who were beyond the customer boundary of traditional advertisement.

Second, according to our social experiments in Table 1, the cultivating forward neighborhood rectangle pursued value proposition, which is produced by changing anything in the supply chain accordingly, such as substitutes. The smart meditation system substituted the forward users from students to meditation actors. The indoor harmful gas emission system changed the value chain from agriculture to housing industry. The interactive smart display advertisement system substituted the one-way advertisement system with a two-way advertisement system. The store signboard-type smart display system substituted the traditional advertisement board as the store signboard.

Third, the cultivating forward neighborhood rectangle focused on a technological system that creates links and promotes collaboration according to our social experiments. The smart meditation system created new links between meditation and traditional products. The indoor harmful gas emission system built new value chains with traditional agriculture value chains focused on emissions. The interactive smart display system created new additional value chains focused on interactive systems. Finally, the store signboard-type system reconfigured their own value chain of users to meet the requirement of the store signboard.

Fourth, the forward neighborhood cultivating rectangle focused on more economical and more compatible cost and revenue according to our social experiment. The smart meditation system attempted 
to move from a transaction-based system to a subscription-based system. The indoor harmful gas emission system attempted to partially move from a product-based system to a service-based system. The interactive smart display advertisement platform and the store signboard-type advertisement system moved from one-time transaction-based systems to subscription-based revenue and cost systems.

Fifth, the forward neighborhood cultivating rectangle pursued different "when" and "where" for decoupling among search, buy, and usage, according to our social experiments. The smart meditation system attempted to meet the requirement of the user community. The indoor harmful gas emission system pursued a customized front end and standardized back end to meet the needs of diverse users. The interactive smart display advertisement system and store signboard-type display system attempted to convert the leaders to customers and decouple among buying and usage.

All four social experiment cases were based on open innovation between protected technology of existing SMEs and the current markets of others or potential markets, as in Figure 5. Through this type of open innovation, the four SMEs could all develop new innovative business models based on their protected technology while retaining the target markets of others or new markets by simply cultivating non-users and changing anything in the supply chain.

\section{Cultivating Backward Neighborhood Rectangular Compass Building and Social Experiment}

\subsection{Concept Model Building of Cultivating Backward Neighborhood Rectangular Compass}

James Watt, who had been appointed as Glasgow College's instrument maker in July 1757, accumulated knowledge on the steam engine by repairing the model engine belonging to John Anderson in the winter of 1763-1764, and ultimately developed successful steam engines in the market by changing and adding complementary goods with the support of Matthew Boulton [82,83]. Steve Jobs and Steve Wozniak got together electronic components, developed by themselves some different complementary goods, and finally invented new products, from Blue Box to new Apple 2, which was based on a totally new concept, that is, a true personal computer [83]. Sergey Brin and Larry Page changed the search engine industry based on page links, which they developed themselves, and expanded huge undeveloped adjacencies that no other search engine company before Google had utilized [84]. Elon Musk and the Tesla engineering team combined several batteries with friction stir welding technology, which had been developed by a national lab in the UK, The Welding Institute (TWI), and changed the complementary parts of an electronic car, thus inventing the Tesla electronic car. Tesla went on to become the first commercially successful car brand in the electronic car industry $[85,86]$.

A cultivating backward neighborhood rectangular concept model can be built from the perspective of engineers like James Watt, Steve Jobs, Brin and Page, or Elon Musk (Figure 6) [11]. First, the customer segmentation of this business model is undeveloped adjacent customers who pursue technologically higher value in addition to functional or spatial undeveloped adjacencies. By thinking technology differently, new customers in the modern market as well as the potential market can be reached [24,87]. Most of all, insisting on the highest standard in technology will expand undeveloped adjacent customers [37]. 




Figure 6. Cultivating backward neighborhood rectangle concept model for engineer-centered business model innovation.

Second, value proposition, the "what "of engineer-centered business model innovation, requires different and complementary goods developed through new ways of thinking about functional and emotional orientation. Technological overfitting must be the way to value proposition innovation in the backward neighborhood if it is to escape the Icarus paradox [88]. Through reverse engineering, it is possible to take lessons on value proposition innovation from future competitors by dismantling, analyzing, and innovating their value propositions [89]. Sometimes, through disruptive technologies, value proposition can arrive at more than a complementary state [90].

Third, the technological system, the "how" of engineer-centered business model innovation, should pursue the balance between creativity and value capture by cultivating the backward neighborhood. With new technological key activities, key partners, or key resources, we can arrive not at a new product but rather at a whole new technological system such as the flywheel on Amazon [37]. Through a technologically driven shift of the system, accumulating customer experiences with high quality and lower cost in the system is possible [91].

Fourth, cost and revenue, the "why" of engineer-centered business model innovation, pursues revenue not in terms of high technology but in terms of high reward. Engineers attempt to decrease time and energy in addition to money as cost [25]. In addition, in the backward neighborhood rectangle, engineers try to calculate strength and opportunity as revenue and weakness and threat as cost [92].

Fifth, customer channel and relations, the "when" and "where" compass of engineer-centered business model innovation, involves the pursuit of technologically creative customer relations in addition to online and web-based channels and bits or virtual-based products [44]. Engineers are currently attempting to build new direct channels using diverse strategies such as upsell, cross-sell, changing third parties, or bundling [93].

Engineers in the backward neighborhood cultivating rectangle can arrive at business model innovation by motivating open innovation between their technology secrets, which were developed by the engineer for this business model even though it was not patented yet, and the existing markets of others, which are located as undeveloped adjacencies, or their potential markets. The market growth ratio can be sizable in this business model innovation because the existing market with undeveloped adjacencies or potential markets together is based on a new and creative secret technology. 


\subsection{Social Experiment and Validation of Cultivating Backward Neighborhood Rectangular Compass}

First, the cultivating backward neighborhood rectangle focused mainly on undeveloped adjacencies with technologically higher value, as in Figure 6, according to the social experiments in Table 1. The smart bench advertisement system pursued undeveloped adjacencies that were accustomed to local benches and shops. The smart locking system and electronic car charge reservation system were designed for customers who think differently in terms of technology and insist on the highest standards. The mobile smart advertisement system and smart measuring system focused on functional undeveloped adjacent customers as well.

Second, the cultivating backward neighborhood rectangle pursued different and complementary goods in terms of value proposition in the social experiments. The smart bench advertisement system pursued a local advertisement system with technologically complementary goods for bench advertisements. The smart locking system and electronic car charge reservation system had value propositions based on technological overfitting to avoid the Icarus paradox. The mobile smart advertisement system and smart measuring system had complementary parts that were based on disruptive technologies.

Third, the cultivating backward neighborhood rectangle focused on technological systems that pursued balance between creativity and value capture, according to the social experiments. The smart bench advertisement system produced not a new product but rather a new local advertisement system by balancing creativity and value capture. The smart locking system and electronic car charge reservation system together were accumulating customer experiences through a technologically driven shift of their systems. The mobile smart advertisement system and smart measuring system had technologically new key activities to build a technological system.

Fourth, according to our social experiments, the backward neighborhood cultivating rectangle focused on revenue with high reward rather than high technology in addition to considering cost as decreasing time, energy, and money all together. The smart bench advertisement system focused on revenue not in terms of high technology but in terms of high reward by trying to connect with the local shop and neighborhood potential customers. The smart locking system and electronic car charge reservation system have high revenue from strength and opportunity and low cost from weakness and threat. The mobile smart advertisement system and smart measuring system took advantage of sizable windows of opportunity, such as the growth of electronic car consumption and the expanding usage of smartphones, as manifest revenue.

Fifth, the backward neighborhood cultivating rectangle pursued technologically creative customer relationships, according to our social experiments. The smart bench advertisement system developed online and web-based channels to meet customers and advertisement targets. The smart locking system and electronic car charge reservation system created online and web channels to meet customers directly at their location. The mobile smart advertisement system and smart measuring system developed creative customer relationships through upselling and cross-selling, such as street persons as advertisement targets and new developments in the usage of smart phones.

All five social experiment cases were based on open innovation between the secret technology of engineers and the current market of others or potential markets, as shown in Figure 6. Engineers may have high quality secret new technologies that can be applied to the modern markets of others, as with the smart bench advertisement system or the mobile smart advertisement system, according to our social experiment. In addition, engineer entrepreneurs can apply their own secret technology to potential new markets such as in the cases of the smart locking system, electronic car charge reservation system, and smart measuring system. 


\section{Discussion and Conclusions}

7.1. Discussion: Open Innovation Dynamics as the Engine for Sustainable and Stepwise Business Model Innovation

According to our social experiments, firms do not stick permanently to any business models. So, to say, business model innovation has an evolutionary aspect that cannot ignore existing business models including now-benefits formulas, or the organizational competence at the level of existing resources and processes. Any firm is always trying to continuously innovate their business model, in other words, stepwise innovation of business models considering organizational capabilities. Furthermore, the source of business model innovation is essentially open innovation, meaning new combinations or connections between technology and market across the boundaries of firms. Different types of open innovation can motivate different rectangular compass business model innovations among overshooting, expanding bottom, forward neighborhood, and backward neighborhood.

That is, through different types of open innovation, different styles of business model innovation can be achieved. First, open innovation between social markets and diverse technology such as open, secret, and protected knowledge can motivate expanding bottom business model innovation. Second, open innovation between potential markets and diverse technology such as open, secret, and protected knowledge can increase overshooting business model innovation. Third, open innovation between protected technology and diverse markets such as current, potential, and social markets can motivate backward neighborhood cultivating business model innovation. Fourth, open innovation between secret technology and diverse markets such as current, potential, and social markets can increase forward neighborhood cultivating business model innovation.

Finally, business model innovation is not a one-time event, but a dynamic evolving process based on the engine of open innovation, as shown in Figure 7. Thus, continuous open innovation is the trigger of business model innovation dynamics as stepwise innovation based on the organizational competence of the firm.

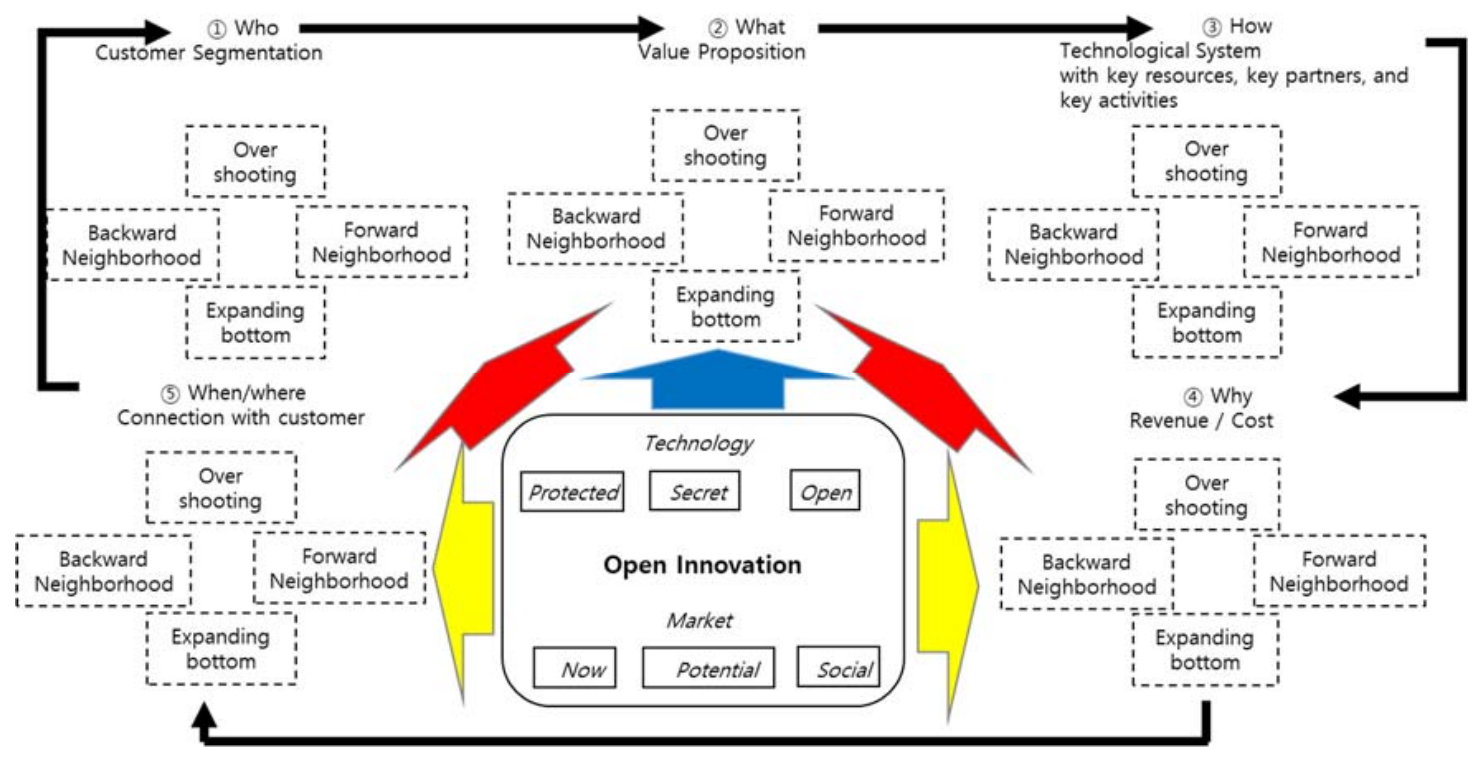

Figure 7. Open innovation as the engine of business model innovation.

\subsection{Conclusions}

\subsubsection{Implications}

First, according to our social experiment, the rectangular compass concept model is highly useful for developing innovative business models or innovating existing business models. 
Second, according to the location in the knowledge funnel, four actors could match four types of business model innovation, such as a customer-overshooting rectangular compass, a social entrepreneur-expanding bottom rectangle compass, a user (existing SMEs)-forward neighborhood cultivating rectangle, and an engineer-backward neighborhood cultivating rectangle. However, beyond these four combinations, the rectangular compass itself is highly useful for developing business model innovation when it is matched with a business model design compass in diverse ways, as in Table 2, even though there are four matching focal points.

Table 2. Diverse matches between rectangular compass and business model design compass.

\begin{tabular}{ccccc}
\hline Rectangle & Overshooting & Expanding Bottom & $\begin{array}{c}\text { Cultivate backward } \\
\text { neighborhood }\end{array}$ & $\begin{array}{c}\text { Cultivate forward } \\
\text { neighborhood }\end{array}$ \\
\cline { 5 - 5 } $\begin{array}{c}\text { MB Design } \\
\text { Compass }\end{array}$ & $\begin{array}{c}\text { (Customer rectangle) } \\
\text { Who }\end{array}$ & $\begin{array}{c}\text { (Social entrepreneur } \\
\text { rectangle) }\end{array}$ & (Engineer rectangle) & \\
\hline What & Market-High value & Social value & Complementary customer & $\begin{array}{c}\text { Substitute } \\
\text { customer }\end{array}$ \\
\hline How & $\begin{array}{c}\text { Market-based new } \\
\text { tech. system }\end{array}$ & $\begin{array}{c}\text { Rediscovering current } \\
\text { tech. system. }\end{array}$ & $\begin{array}{c}\text { Tech. based new } \\
\text { tech. system }\end{array}$ & $\begin{array}{c}\text { Re-arranging of } \\
\text { now tech. system }\end{array}$ \\
\hline Why & $\begin{array}{c}\text { Higher revenue and } \\
\text { lower cost from market }\end{array}$ & Low revenue and low cost & $\begin{array}{c}\text { Higher revenue and lower } \\
\text { cost from technology }\end{array}$ & $\begin{array}{c}\text { Different revenue } \\
\text { and different cost }\end{array}$ \\
\hline When and Where & $\begin{array}{c}\text { Customer-oriented } \\
\text { channel and time }\end{array}$ & Rare channel and rare time & $\begin{array}{c}\text { Direct channel and } \\
\text { now time }\end{array}$ & $\begin{array}{c}\text { Different channel } \\
\text { and different time }\end{array}$ \\
\hline
\end{tabular}

Third, the process of business model innovation is not a linear process but a dynamic cycling process with open innovation dynamics. From a thinking experiment to real business model development, the rectangular compass can be used as a powerful concept model of business model innovation dynamics.

\subsubsection{Limitations and Future Research Goals}

The rectangular compass is itself a concept model for business model innovation based on open innovation dynamics. Thus, the rectangular compass will be adapted according to the economic environment and firm situation.

Therefore, first, the evolution of the rectangular compass including open innovation strategy contents, open innovation culture including trust, or system dynamic feedback loop of open innovation should be adjusted according to the economic situation.

Second, differentiation of the rectangular compass according to the difference of capitalist economy, such as matured capitalism, or based on the developing capitalism or belated capitalism, should be considered in future research. The difference of sectors may provide further detail regarding the concept developing of the rectangular compass. According to the situation of capitalism, and the sector to which the firm belongs, concrete and fascinated rectangle compasses should be developed and related knowledge should be accumulated.

Third, and most importantly, by applying this concept model to business model innovation, more validation of the rectangular compass should be obtained from users beyond the social experiments of this study, and more practical value should be sought by elaborating this model based on the recommendations of users. Continuous business model innovation by rectangle compass is not just for conquering the growth limits of capitalism of firms, but also for escaping the arrow information paradox and Death Valley. In firms, universities, or start-ups, rectangle compass could and should be used for the real value creation requirement.

Author Contributions: Conceptualization, investigation, and writing-original draft preparation, J.J.Y.; project administration, writing-review and editing, X.Z. All authors have read and agreed to the published version of the manuscript. 
Funding: This paper was presented as a keynote speech of SOI 2020, and the publishing fee was supported by SOI. Acknowledgments: This work was supported by the DGIST R\&D program of the Ministry of Science and ICT (19-IT-01, 20-IT-10-02).

Conflicts of Interest: The authors declare no conflict of interest.

\section{References}

1. Chesbrough, H. Open Innovation Results: Going Beyond the Hype and Getting Down to Business; Oxford University Press: Oxford, UK, 2019.

2. Cooke, P. World Turned Upside Down: Entrepreneurial Decline, Its Reluctant Myths and Troubling Realities. J. Open Innov. Technol. Mark. Complex. 2019, 5, 22. [CrossRef]

3. Pyka, A.; Bogner, K.; Urmetzer, S. Productivity Slowdown, Exhausted Opportunities and the Power of Human Ingenuity—Schumpeter Meets Georgescu-Roegen. J. Open Innov. Technol. Mark. Complex. 2019, 5, 39. [CrossRef]

4. Yun, J.J.; Park, K.; Hahm, S.D.; Kim, D. Basic Income with High Open Innovation Dynamics: The Way to the Entrepreneurial State. J. Open Innov. Technol. Mark. Complex. 2019, 5, 41. [CrossRef]

5. Yun, J.J.; Won, D.; Park, K. Entrepreneurial cyclical dynamics of open innovation. J. Evol. Econ. 2018, 28, 1151-1174. [CrossRef]

6. Yun, J.J. How do we conquer the growth limits of capitalism? Schumpeterian Dynamics of Open Innovation. J. Open Innov. Technol. Mark. Complex. 2015, 1, 1-20. [CrossRef]

7. Yun, J.J.; Liu, Z. Micro- and Macro-Dynamics of Open Innovation with a Quadruple-Helix Model. Sustainability 2019, 11, 3301. [CrossRef]

8. Johnson, M.W.; Christensen, C.M.; Kagermann, H. Reinventing your business model. Harv. Bus. Rev. 2008, 86, 57-68.

9. Osterwalder, A.; Pigneur, Y. Business Model Generation: A Handbookfor Visionaries, Game Changers, and Challengers; John Wiley \& Sons: Hoboken, NJ, USA, 2010.

10. Chesbrough, H. Open Business Models: How to Thrive in the New Innovation Landscape; Harvard Business Press: Brighton, MA, USA, 2006.

11. Yun, J.J. Business Model Design Compass: Open Innovation Funnel to Schumpeterian New Combination Business Model Developing Circle; Springer: Singapore, 2017.

12. Weill, P.; Woerner, S.L. Optimizing your digital business model. MIT Sloan Manag. Rev. 2013, 54, 71. [CrossRef]

13. Teece, D.J. Business Models, Business Strategy and Innovation. Long Range Plan. 2010, 43, 172-194. [CrossRef]

14. Lee, J.; Suh, T.; Roy, D.; Baucus, M. Emerging Technology and Business Model Innovation: The Case of Artificial Intelligence. J. Open Innov. Technol. Mark. Complex. 2019, 5, 44. [CrossRef]

15. Čirjevskis, A. The Role of Dynamic Capabilities as Drivers of Business Model Innovation in Mergers and Acquisitions of Technology-Advanced Firms. J. Open Innov. Technol. Mark. Complex. 2019, 5, 12. [CrossRef]

16. Müller, M.; Vorraber, W.; Slany, W. Open Principles in New Business Models for Information Systems. J. Open Innov. Technol. Mark. Complex. 2019, 5, 6. [CrossRef]

17. Schneider, S.; Spieth, P. Business Model Innovation: Towards an Integrated Future Research Agenda. Int. J. Innov. Manag. 2013, 17, 1-34. [CrossRef]

18. Chernev, A. The Business Model: How to Develop New Products, Create Market Value and Make the Competition Irrelevant; Cerebellum Press: Chicago, IL, USA, 2017.

19. Schumpeter, J.A. The Theory of Economic Development; Transaction Publishers: New Brunswick, NJ, USA, 1934.

20. Chesbrough, H.W. Open Innovation: The New Imperative for Creating and Profiting from Technology; Harvard Business Press: Brighton, MA, USA, 2003.

21. Chesbrough, H. Business Model Innovation: Opportunities and Barriers. Long Range Plan. 2010, 43, $354-363$. [CrossRef]

22. Chesbrough, H. Business model innovation: It's not just about technology anymore. Strat. Leadersh. 2007, 35, 12-17. [CrossRef]

23. Saebi, T.; Foss, N.J. Business models for open innovation: Matching heterogeneous open innovation strategies with business model dimensions. Eur. Manag. J. 2015, 33, 201-213. [CrossRef]

24. Yun, J.J.; Yang, J.; Park, K. Open Innovation to Business Model. Sci. Technol. Soc. 2016, 21, 324-348. [CrossRef] 
25. Osterwalder, A.; Pigneur, Y.; Bernarda, G.; Smith, A. Value Proposition Design: How to Create Products and Services Customers Want; John Wiley \& Sons: Hoboken, NJ, USA, 2014.

26. Blank, S. The Four Steps to the Epiphany; K \& S Ranch: Pescadero, CA, USA, 2013.

27. Kim, W.C.; Mauborgne, R. Blue Ocean Shift: Beyond Competing- Proven Steps to Inspire Confidence and Seize New Growth; Hachette: London, UK, 2017.

28. Bower, J.L.; Christensen, C.M. Disruptive Technologies: Catching the Wave. J. Prod. Innov. Manag. 1995, 1, 75-86.

29. Lyons, A.C.; Mondragon, A.E.C.; Piller, F.; Poler, R. Customer-Driven Supply Chains: From Glass Pipelines to Open Innovation Networks; Springer: London, UK, 2012.

30. Schumpeter, J.A. Capitalism, Socialism and Democracy; Routledge: New York, NY, USA, 1942.

31. Vickrey, W. Public Economics: Selected Papers by William Vickrey; Cambridge University Press: Cambridge, UK, 1997.

32. Simon, H.A. Bounded Rationality and Organizational Learning. Organ. Sci. 1991, 2, 125-134. [CrossRef]

33. Isaacson, W. Steve Jobs; Little Brown: London, UK, 2011.

34. Schlender, B.; Tetzeli, R. Becoming Steve Jobs; Crown Business: New York, NY, USA, 2015.

35. Roy, R. Case studies of creativity in innovative product development. Des. Stud. 1993, 14, 423-443. [CrossRef]

36. Isaacson, W. Steve Jobs, Italian ed.; Edizioni Mondadori: Milan, Italy, 2011.

37. Rossman, J. The Amazon Way: 14 Leadership Principles Behind the World's Most Disruptive Company; Clyde Hill Publishing: Washington, DC, USA, 2016; Volume 1.

38. Urban, G.L.; Von Hippel, E. Lead User Analyses for the Development of New Industrial Products. Manag. Sci. 1988, 34, 569-582. [CrossRef]

39. Ries, E. The Lean Startup: How Today's Entrepreneurs Use Continuous Innovation to Create Radically Successful Businesses; Currency: New York, NY, USA, 2011.

40. Muehlhausen, J. Business Models for Dummies; John Wiley \& Sons: Hoboken, NJ, USA, 2013.

41. Kaplan, S. The Business Model Innovation Factory: How to Stay Relevant When the World is Changing; John Wiley \& Sons: Hoboken, NJ, USA, 2012.

42. Chesbrough, H. Open Services Innovation: Rethinking Your Business to Grow and Compete in a New Era; John Wiley \& Sons: Hoboken, NJ, USA, 2011.

43. Tzuo, T.; Weisert, G. Subscribed: Why the Subscription Model Will be Your Company's Future-and What to Do about it; Penguin: London, UK, 2018.

44. Blank, S.; Dorf, B. The Startup Owner's Manual: The Step-by-Step Guide for Building a Great Company; John Wiley \& Sons: Hoboken, NJ, USA, 2020.

45. Alexander, M. Bright Lights, No City: An African Adventure on Bad Roads with a Brother and a Very Weird Business Plan; Hyperion: Westport, CT, USA, 2012.

46. Gupta, A.K. Grassroots Innovation: Minds on the Margin Are Not Marginal Minds; Random House India: Gurugram, India, 2016.

47. Yun, J.J.; Egbetoku, A.A.; Zhao, X. How Does a Social Open Innovation Succeed? Learning from Burro Battery and Grassroots Innovation Festival of India. Sci. Technol. Soc. 2018, 24, 122-143. [CrossRef]

48. Chesbrough, H.; Di Minin, A. Open social innovation. In New Frontiers in Open Innovation; Chesbrough, H., Vanhaverbeke, W., West, H., Eds.; Oxford University Press: Oxford, MS, USA, 2014; pp. 301-315.

49. Yun, J.J.; Park, K.; Im, C.; Shin, C.; Zhao, X. Dynamics of Social Enterprises-Shift from Social Innovation to Open Innovation. Sci. Technol. Soc. 2017, 22, 425-439. [CrossRef]

50. Porter, M.E.; Kramer, M.R. Creating Shared Value, in Managing Sustainable Business; Springer: Dordrecht, The Netherlands, 2019; pp. 323-346.

51. Mulgan, G. The Locust and the Bee: Predators and Creators in Capitalism's Future-Updated Edition; Princeton University Press: Princeton, NJ, USA, 2015.

52. Brooks, A.C. Social Entrepreneurship: A Modern Approach to Social Value; Pearson Prentice Hall: Upper Saddle River, NJ, USA, 2009.

53. Lin, C.Y.-Y.; Chen, J. Impact of Societal and Social Innovation; Springer: Singapore, 2016.

54. Kanter, R.M. How to do well and do good. MIT Sloan Manage. Rev. 2010, 52, 12.

55. Deaton, A. The Great Escape: Health, Wealth, and the Origins of Inequality; Princeton University Press: Princeton, NJ, USA, 2013.

56. Piketty, T. About Capital in the Twenty-First Century. Am. Econ. Rev. 2015, 105, 48-53. [CrossRef] 
57. Manzini, E. Design, When Everybody Designs: An Introduction to Design for Social Innovation; MIT Press: Cambridge, MA, USA, 2015.

58. Hamari, J.; Sjoklint, M.; Ukkonen, A. The Sharing Economy: Why People Participate in Collaborative Consumption. J. Assoc. Inf. Sci. Technol. 2016, 67, 2047-2059. [CrossRef]

59. Rifkin, J. The Sero Marginal Cost Society: The Internet of Things, the Collaborative Commons, and the Eclipse of Capitalism; St. Martin's Press: New York, NY, USA, 2014.

60. Börgers, T. An Introduction to the Theory of Mechanism Design; Oxford University Press: New York, NY, USA, 2015.

61. Botsman, R.; Rogers, R. What's Mine is Yours: The Rise of Collaborative Consumption; Hyper-Collins: London, UK, 2010.

62. Posner, E.A.; Weyl, E.G. Radical Markets: Uprooting Capitalism and Democracy for a Just Society; Princeton University Press: Princeton, NJ, USA, 2018.

63. Grant, A.M. Give and Take: A Revolutionary Approach to Success; Penguin: London, UK, 2013.

64. Dyson, J.; Gammack, P.D.; Crawford, T.V.H. Fan. U.S. Patent Application No 29/331,008, 13 October 2009.

65. Yun, J.J.; Park, K. How User Entrepreneurs Succeed: The Role of Entrepreneur's Caliber and Networking Ability in Korean User Entrepreneurship. Sci. Technol. Soc. 2016, 21, 391-409. [CrossRef]

66. Von Hippel, E. Democratizing innovation: The evolving phenomenon of user innovation. Int. J. Innov. Sci. 2005, 55, 63-78. [CrossRef]

67. Yun, J.J.; Yigitcanlar, T. Open Innovation in Value Chain for Sustainability of Firms. Sustainability 2017, 9, 811. [CrossRef]

68. Hewing, M. Collaboration with Potential Users for Discontinuous Innovation: Experimental Research on User Creativity; Springer Gabler: Wiesbaden, Germany, 2013.

69. Ramaswamy, V.; Gouillart, F. Building the co-creative enterprise. Harv. Bus. Rev. 2010, 88, 100-109.

70. Demarco, M. Life, Liberty, and the Pursuit of Entrepreneurship; Viperion Publishing Corporation: Fountain Hills, AZ, USA, 2017.

71. Kim, W.C.; Mauborgne, R. Blue Ocean Strategy, Expanded Edition: How to Create Uncontested Market Space and Make the Competition Irrelevant; Harvard Business Review Press: Brighton, MA, USA, 2014.

72. Bahcall, S. Loonshots: How to Nurture the Crazy Ideas That Win Wars, Cure Diseases, and Transform Industries; St. Martin's Press: New York, NY, USA, 2019.

73. Harhoff, D.; Lakhani, K.R. Revolutionizing Innovation: Users, Communities, and Open Innovation; MIT Press: Cambridge, MA, USA, 2016.

74. Govindarajan, V.; Trimble, C. Building breakthrough businesses within established organizations. Harv. Bus. Rev. 2005, 83, 58-68. [PubMed]

75. Foss, N.J.; Saebi, T. Business Model Innovation: The Organizational Dimension; OUP: Oxford, UK, 2015.

76. Chisholm, J. Unleash Your Inner Company: Use Passion and Perseverance to Build Your Ideal Business; Greenleaf Book Group: Austin, TX, USA, 2015.

77. Newth, F. Business Models and Strategic Management: A New Integration; Business Expert Press: New York, NY, USA, 2012.

78. Teixeira, T.S.; Piechota, G. Unlocking the Customer Value Chain: How Decoupling Drives Consumer Disruption; Currency: New York, NY, USA, 2019.

79. Hienerth, C.; Von Hippel, E.; Jensen, M.B. User community vs. producer innovation development efficiency: A first empirical study. Res. Policy 2014, 43, 190-201. [CrossRef]

80. West, J.; Gallagher, S. Challenges of open innovation: The paradox of firm investment in open-source software. RED Manag. 2006, 36, 319-331. [CrossRef]

81. Halligan, B.; Shah, D. Inbound Marketing: Get Found Using Google, Social Media, and Blogs; John Wiley \& Sons: Hoboken, NJ, USA, 2009.

82. Russell, B. James Watt: Making the World Anew; Reaktion Books: Islington, London, UK, 2014.

83. Yun, J.J.; Jung, K.; Yigitcanlar, T. Open Innovation of James Watt and Steve Jobs: Insights for Sustainability of Economic Growth. Sustainability 2018, 10, 1553. [CrossRef]

84. Vise, D. The Google Story. Strat. Dir. 2007, 23. [CrossRef]

85. Morris, C. Tesla Motors: How Elon Musk and Company Made Electric Cars Cool, and Sparked the Next Tech Revolution; Smashwords Edition: Los Gatos, CA, USA, 2014. 
86. Vance, A. Elon Musk: Tesla, SpaceX, and the Quest for a Fantastic Future; HarperCollins: New York, NY, USA, 2015.

87. Zott, C.; Amit, R.; Massa, L. The business model: Recent developments and future research. J. Manag. 2011, 37, 1019-1042. [CrossRef]

88. Wanetick, D. Business Model Validation: What Makes Business Models Work? Lulu Press, Inc.: Morrisville, NC, USA, 2015.

89. Gassmann, O.; Frankenberger, K.; Csik, M. The Business Model Navigator: 55 Models that Will Revolutionise Your Business; Pearson: London, UK, 2014.

90. Afuah, A. Business Model Innovation: Concepts, Analysis, and Cases; Routledge: New York, NY, USA, 2014.

91. Johnson, M.W.; Lafley, A.G. Seizing the White Space: Business Model Innovation for Growth and Renewal; Harvard Business Press: Brighton, MA, USA, 2010.

92. Kumar, V. 101 Design Methods: A Structured Approach for Driving Innovation in Your Organization; John Wiley \& Sons: Hoboken, NJ, USA, 2012.

93. Bryce, D.J.; Dyer, J.H.; Hatch, N.W. Competing against free. Harv. Bus. Rev. 2011, 89, 104.

Publisher's Note: MDPI stays neutral with regard to jurisdictional claims in published maps and institutional affiliations.

(C) 2020 by the authors. Licensee MDPI, Basel, Switzerland. This article is an open access article distributed under the terms and conditions of the Creative Commons Attribution (CC BY) license (http://creativecommons.org/licenses/by/4.0/). 